\title{
Effect of dobutamine on the clinical course of preterm infants with mild hyaline membrane disease
}

Sudigdo Sastroasmoro

\begin{abstract}
Abstrak
Status kardiovaskular dan peran dobutamin terhadapnya belum pernah diteliti pada pasien dengan penyakit membran hialin (PMH) ringan. Tujuan penelitian ini adalah untuk mengetahui pengaruh pemberian dobutamin pada pasien PMH ringan (PMH yang tidak memerlukan pemberian ventilasi mekanik). Pasien PMH ringan dilakukan randomisasi, untuk diberikan dobutamin atau plasebo, selain pengobatan suportif standar yang berlaku di Subbagian Perinatologi, Bagian Ilmu Kesehatan Anak FKUI-RSCM, Jakarta. Pengobatan diberikan sampai setiap pasien berusia 96 jam atau bila terjadi kegagalan (memerlukan ventilasi mekanik atau mengalami perburukan yang mengancam jiwa). Empat puluh satu pasien disertakan dalam penelitian; 21 diberikan plasebo, 20 mendapat dobutamin $10 \mu \mathrm{g} / \mathrm{kg} /$ menit. Selama perlakuan tidak terdapat perbedaan yang bermakna dalam laju jantung dan laju napas antara kedua kelompok, namun tekanan sistolik, tekanan diastolik, dan tekanan arteri rerata secara bermakna lebih tinggi pada kelompok dobutamin dibanding pada kelompok plasebo. Terdapat 8 pasien yang mengalami kegagalan pada kelompok plasebo, dan 7 pada kelompok dobutamin, termasuk 1 pasien yang mengalami peningkatan tekanan darah sistolik sampai 85 mmHg. Uji $x^{2}$ tidak memperlihatkan perbedaan kegagalan antara kedua kelompok, namun analisis kesintasan (survival analysis) dengan menggunakan metode Kaplan-Meier dan uji Breslow menunjukkan bahwa pasien kelompok dobutamin mempunyai masa bebas ventilasi mekanik dan perburukan klinis (rerata 78 jam, interval kepercayaan 95\% antara 70 sampai 84 jam) lebih lama dibandingkan dengan pasien kelompok plasebo (rerata kesintasan 61 jam, interval kepercayaan 95\% antara 51 sampai 71 jam). Disimpulkan bahwa penambahan dobutamin pada terapi suportif standar memperlambat perburukan klinis NKB dengan PMH ringan, sehingga dianjurkan pemberian dobutamin $10 \mu \mathrm{g} / \mathrm{kg} /$ minute secara dini pada pasien PMH ringan.
\end{abstract}

\begin{abstract}
In contrast to the situation in severe hyaline membrane disease (HMD), cardiovascular status and effect of inotropic agent in mild HMD have not been investigated. This study aimed to study the effect of dobutamine on the clinical course of mild HMD. Preterm infants with mild HMD (those who did not require mechanical ventilation) were randomly assigned to either receive dobutamine $10 \mu \mathrm{g} / \mathrm{kg} / \mathrm{minute}$ or placébo in addition to standard supportive treatment. All patients were managed according to standard treatment at the Division of Perinatology, Department of Child Health, Medical School, University of Indonesia. The treatment was continued until each patient reached the age of 96 hours, or needed mechanical ventilation, or experienced life threatening clinical deterioration. Forty-one infants were enrolled in the study; 20 were treated with dobutamine and 21 with placebo. Clinical observation disclosed that there was no difference between heart rate and respiratory rate between the 2 groups, but systolic, diastolic, and mean arterial blood pressures were significantly higher in dobutamine-treated than in placebo-treated group. There were 8 failures in placebo group and 7 failures (including I with systolic hypertension) in the dobutamine group. There was no significant difference of the occurrence of treatment failure between the two groups. However, on survival analysis using Kaplan-Meier and Breslow testing it was observed that dobutamine-treated patients had a significantly longer mean mechanical-ventilation-free survival (mean: 78 hours; $95 \%$ confidence intervals: 70; 84 hours) than placebo-treated patients (mean: 61 hours; 95\% confidence intervals 51;71 hours). Administration of dobutamine to standard treatment delays the deterioration of preterm infants with mild HMD, so that use of dobutamine $10 \mu \mathrm{g} / \mathrm{kg} /$ minute early in the course of the disease is recommended.
\end{abstract}

Keywords: Dobutamine, preterm infants, hyaline membrane disease, mechanical ventilation free survival

Hyaline membrane disease (HMD) is one of the most challenging problems in neonatal period both in

Department of Child Health, Faculty of Medicine, University of Indonesia/Dr. Cipto Mangunkusumo Hospital, Jakarta, Indonesia developing and in industrial countries, ${ }^{1}$ as it causes significant perinatal morbidity and mortality. In Indonesia alone not less than 150,000 preterm infants suffered from respiratory distress syndrome (RDS) yearly, mostly due to HMD. This disease is caused by deficiency of surfactant, a surface active agent that prevents the alveoli from atelectasis. Surfactant is syn- 
thesized by type II pneumocytes, starting at 22 weeks gestational age and reaching its optimal amount at term..$^{2-3}$ The clinical course of HMD varies widely. In almost all instances the clinical manifestations of respiratory distress syndrome have appeared by the age of 4 hours. ${ }^{4}$ A proportion of patients present themselves with breathing difficulty at birth, and become more severe in the subsequent hours and days. The usual clinical course, however, is that the symptoms and signs become worse in the first 48 hours, then tend to be plateau for the next 24 hours, followed by gradual improvement in 1-2 days. While patients present themselves with severe manifestations usually persist in severe condition, those who initially present with mild respiratory distress may become severe so that mechanical ventilation is required.

Proper management of severe HMD requires sophisticated technology, i.e., use of mechanical ventilation with or without surfactant replacement therapy. ${ }^{5,6}$ The two modalities are not available for most patients because of problems with facility and cost. One of the complications of HMD is its effects on the cardiovascular system. In severe HMD the cardiac functions are disturbed; ${ }^{7,8}$ however, in mild form of HMD this has not been elucidated. Since cardiac functions are disturbed in severe HMD, it is logical to assume that in mild HMD the cardiac functions are also disturbed in a lesser degree. Furthermore, dobutamine, a titrable inotropic agent which is known to improve cardiovascular function in severe form of HMD, has not been studied in patients with mild HMD. Consequently, the role of inotropic agent on the clinical course of patients is not known. The purpose of this study was to determine the clinical course of patients with mild HMD following continuous infusion of dobutamine.

\section{METHODS}

This was a double blind, randomized placebo-controlled clinical trial to determine the clinical course of preterm infants initially diagnosed as mild HMD following dobutamine infusion. The study was conducted at the Departments of Child Health and Obstetrics and Gynecology, Dr. Cipto Mangunkusumo Hospital, Jakarta, from November 1997 through May 1998. The diagnosis of HMD was based on clinical and radiological criteria. ${ }^{4}$ Preterm infant with HMD was judged to have mild disease when he or she did not require mechanical ventilation support (see below). To be eligible for the study, a patient with mild HMD had to be less than 37 completed weeks of gestation, weighed more than 1250 grams, and aged less than 48 hours at the time of enrollment. Infants who met the inclusion criteria were excluded from the study if there was any of the followings: twins, had structural heart disease except persistent ductus arteriosus, had an overt severe congenital disease, or if the parents disagreed to join the study.

This study was a part of a larger study to determine physiological and epidemiological aspects of preterm infants with HMD. Patients who met the study criteria were randomized by using computer-generated randomization scheme, to either receive dobutamine (Dobutamine, Giulini ${ }^{\mathrm{R}}, 10 \mu \mathrm{g} / \mathrm{kg} /$ minute) or placebo. Clinical and laboratory characteristics were examined before the study, including complete physical examination, blood gases analysis, and electrolyte examination. All infants were treated in the incubator with the ambient temperature of $35^{\circ} \mathrm{C}$ and humidity of $90^{\circ}$. Oxygen were given $2-41 /$ minute by using a nasal catheter or a head box. Prophylactic antibiotic (intravenous amoxycillin $50 \mathrm{mg} / \mathrm{kg} / \mathrm{day}$ ) was given. The clinical condition was continuously monitored, while acid-base and electrolyte measurements were repeated every 12 hours, and if the clinical condition dictated. Head ultrasound to detect evidence of periventricularintraventricular hemorrhage (PIVH) was done on day 3 or 4 by a pediatric radiologist. The study was terminated when the infant had reached the age of 96 hours, or if he or she needed mechanical ventilation, or if life threatening deterioration of any cause occurred. The criteria for mechanical ventilation support were: $\mathrm{PaCO}_{2}>65 \mathrm{mmHg}$ for babies $>1500$ grams or $>50 \mathrm{mmHg}$ for babies $<1500$ grams, with $\mathrm{pH}<7.2$. $^{9}$

All patients received standard management according to the procedure used at the Division of Perinatology, Department of Child Health, Medical School, University of Indonesia. They were managed by pediatric residents under the supervision of perinatologists. All clinical observations, examinations, medications and procedures were recorded. The investigator observed but did not interfere with the patient care and management.

The sample size was estimated by the use of QuickBASIC 4.0 (Microsoft Inc.) Emulates Worksheet Page-7 / CRC Handbook of Sample Size Guidelines for Clinical Trials program. Assuming that the accrual rate was 1 patient every 48 hours, maximal observation duration was 96 hours, control group survival at end point $=0.70$ and survival improvement with dobutamine administration $=0.25, \alpha=0.05$ and power $=0.80$, then 27 patients per group were required.

Analyses were performed in 2 ways. First, usual $x^{2}$ test for independent groups was performed for comparing 
failures in both groups. Second, analysis considering the time of event (time dependent analysis) of patients was performed, since what was important was not only whether the failure had occurred, but also how long after the beginning of treatment it occurred. For this purpose, survivals of patients in dobutamine and placebo groups were constructed by using KaplanMeier method, and Breslow test was applied for comparing the survivals between the two groups. Parental informed consent was obtained from every patient. The study protocol has been approved by the Research Ethical Committee of the Medical School, University of Indonesia.

\section{RESULTS}

There were 41 patients met the study criteria, consisted of 23 males and 18 females. The gestational age ranged from 27 to 35 (mean 32.3, SD 2.7) weeks while the birth weight ranged from 1250 to 2230 (mean 1689, SD 294) grams. Twenty patients received dobutamine $10 \mu \mathrm{g} / \mathrm{kg} /$ minute while the other 21 received placebo, each of them was given by an infusion pump. The clinical and laboratory characteristics of both groups are depicted in Table 1. No apparent difference was found in any of the characteristics.
Comparison of clinical and laboratory characteristics between placebo and dobutamine groups during the study was performed by presenting the values at hours $0,24,48$, and 60 after the beginning of the intervention (Figure 1 and Table 2). Since some of the patients were excluded from the study and the number of patients was getting smaller, comparison was only done until 60 hours after the beginning of the intervention.

\section{Vital signs}

The patient clinical condition, especially heart rate, respiratory rate, systolic and diastolic blood pressures, and mean arterial pressure were examined every 12 hours. Figure 1 shows the comparison of mean vital sign values of dobutamine and placebo groups at hours $0,24,48$, and 60 . Since some patients were excluded from the study due to clinical deterioration, the number of patients in each time of evaluation was different (decreased). This figure shows that there were no significant differences in mean heart rate and respiratory rate in both groups. On the other hand, mean arterial pressure in the dobutamine group was higher than that in the placebo group; this difference was clinically significant and was statistically close to the significance value $(p=0.056)$.

Table 1. Comparison of clinical and laboratory characteristics of dobutamine and placebo groups

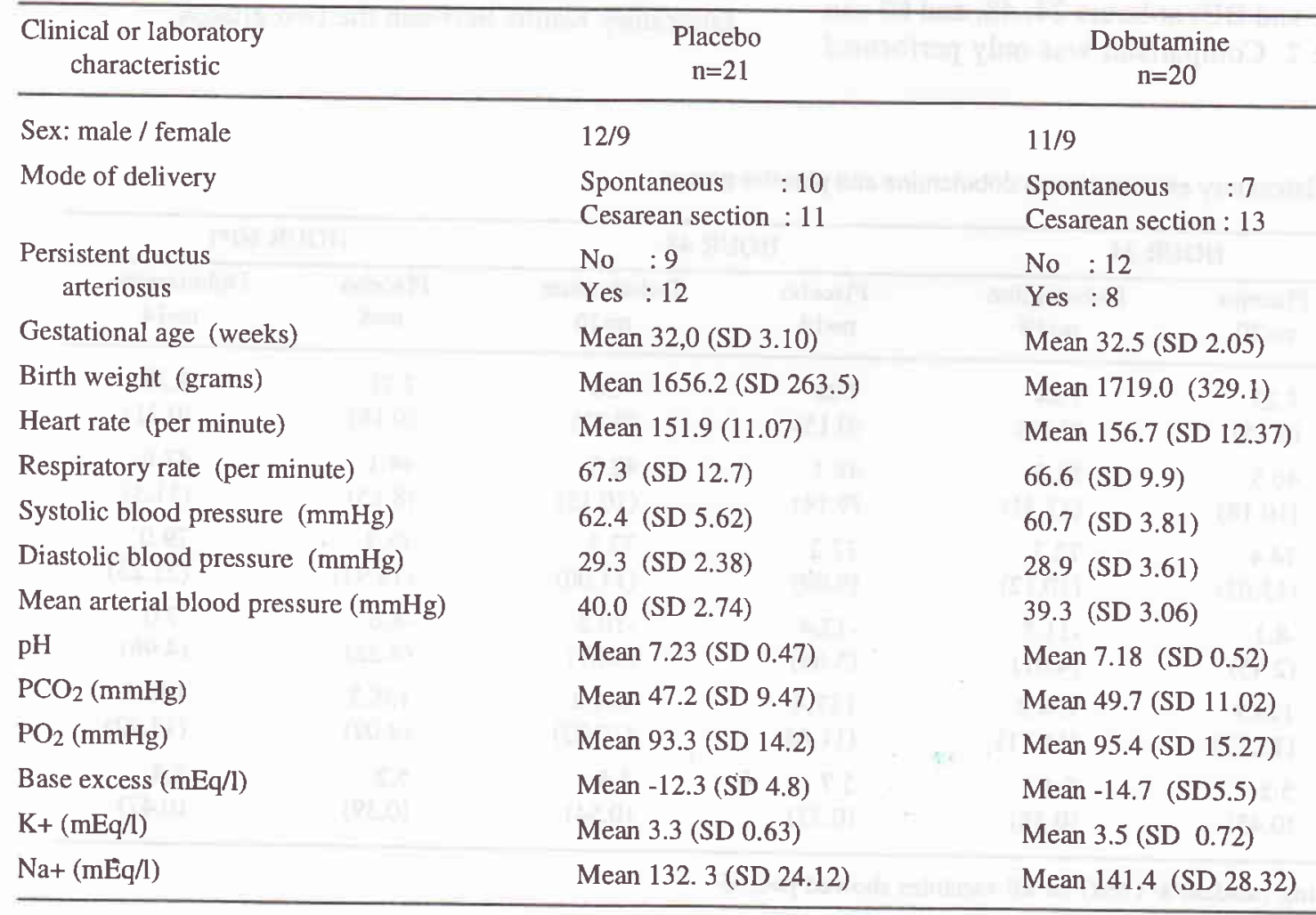




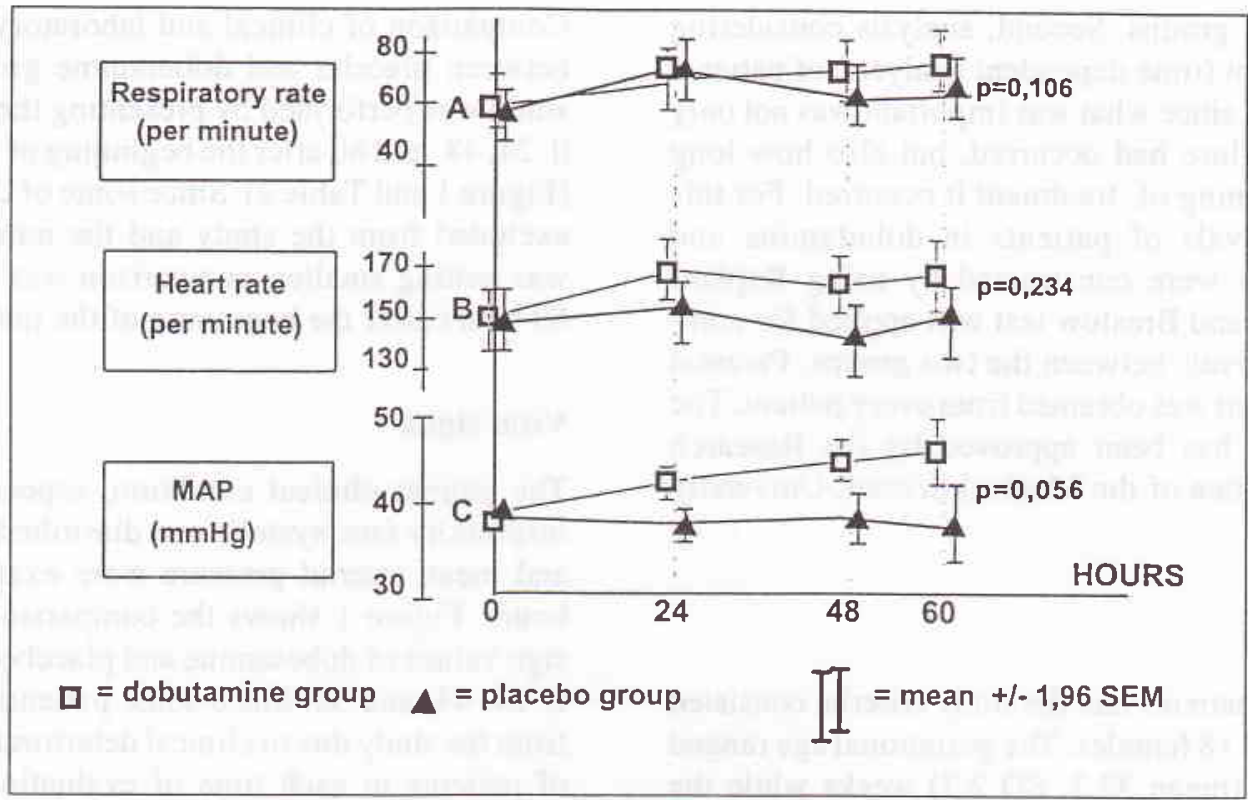

Figure 1. Diagram shows vital signs at the beginning of the study and 24, 28, and 60 hours later.

$M A P=$ mean arterial pressure; $S E M=$ standard error of the mean.

\section{Laboratory results}

Besides physical examination, every 12 hours each patient underwent blood gases and electrolyte analyses. The mean value of the blood gases analysis ( $\mathrm{pH}, \mathrm{PCO}_{2}, \mathrm{PO}_{2}$, and $\mathrm{BE}$ ) at hours 24,48 , and 60 can be seen in Table 2. Comparison was only performed until 60 hours after dobutamine or placebo administration, since at hour 72 there was only 1 patient of the placebo group remained in the study. Hypothesis testing performed by t-test for 2 independent groups at hour 60 disclosed no significant difference of the laboratory results between the two groups.

Table 2. Results of laboratory examination in dobutamine and placebo groups

\begin{tabular}{|c|c|c|c|c|c|c|}
\hline & \multicolumn{2}{|c|}{ HOUR 24} & \multicolumn{2}{|c|}{ HOUR 48} & \multicolumn{2}{|c|}{ HOUR 60*) } \\
\hline & $\begin{array}{c}\text { Placebo } \\
n=20\end{array}$ & $\begin{array}{c}\text { Dobutamine } \\
\mathrm{n}=19\end{array}$ & $\begin{array}{c}\text { Placebo } \\
\mathrm{n}=14\end{array}$ & $\begin{array}{c}\text { Dobutamine } \\
\mathrm{n}=16\end{array}$ & $\begin{array}{c}\text { Placebo } \\
n=8\end{array}$ & $\begin{array}{c}\text { Dobutamine } \\
n=14\end{array}$ \\
\hline $\begin{array}{l}\mathrm{pH} \\
\text { Mean (SD) }\end{array}$ & $\begin{array}{l}7.23 \\
(0.15)\end{array}$ & $\begin{array}{l}7.24 \\
(0.14)\end{array}$ & $\begin{array}{l}7.28 \\
(0.15)\end{array}$ & $\begin{array}{l}7.30 \\
(0.21)\end{array}$ & $\begin{array}{l}7.21 \\
(0.18)\end{array}$ & $\begin{array}{l}7.23 \\
(0.21)\end{array}$ \\
\hline $\begin{array}{l}\mathrm{PCO}_{2}, \mathrm{mmHg} \\
\text { Mean (SD) }\end{array}$ & $\begin{array}{l}46.5 \\
(10.18)\end{array}$ & $\begin{array}{l}52.5 \\
(13.31)\end{array}$ & $\begin{array}{l}48.1 \\
(9.14)\end{array}$ & $\begin{array}{l}42.0 \\
(10.13)\end{array}$ & $\begin{array}{l}44.1 \\
(8.15)\end{array}$ & $\begin{array}{l}47.6 \\
(11.3)\end{array}$ \\
\hline $\begin{array}{l}\mathrm{PO}_{2}, \mathrm{mmHg} \\
\text { Mean (SD) }\end{array}$ & $\begin{array}{l}74.4 \\
(13.03)\end{array}$ & $\begin{array}{l}72.7 \\
(10.12)\end{array}$ & $\begin{array}{l}77.2 \\
(9.09)\end{array}$ & $\begin{array}{l}72.2 \\
(11.00)\end{array}$ & $\begin{array}{l}75.3 \\
(13.91)\end{array}$ & $\begin{array}{l}79.0 \\
(21.23)\end{array}$ \\
\hline $\begin{array}{l}\text { BE, mEq/1 } \\
\text { Mean (SD) }\end{array}$ & $\begin{array}{l}-8.1 \\
(2.45)\end{array}$ & $\begin{array}{l}-11.3 \\
(4.01)\end{array}$ & $\begin{array}{l}-12.4 \\
(5.66)\end{array}$ & $\begin{array}{l}-10.2 \\
(4.07)\end{array}$ & $\begin{array}{l}-8.6 \\
(4.22)\end{array}$ & $\begin{array}{l}-7.0 \\
(4.96)\end{array}$ \\
\hline $\begin{array}{l}\mathrm{Na}+, \mathrm{mEq} / \mathrm{l} \\
\text { Mean (SD) }\end{array}$ & $\begin{array}{l}128.3 \\
(13.22)\end{array}$ & $\begin{array}{l}134.2 \\
(14.71)\end{array}$ & $\begin{array}{l}137.4 \\
(11.64)\end{array}$ & $\begin{array}{l}134.2 \\
(10.02)\end{array}$ & $\begin{array}{l}138.2 \\
(9.09)\end{array}$ & $\begin{array}{l}136.9 \\
(13.22)\end{array}$ \\
\hline $\begin{array}{l}\mathrm{K}+, \mathrm{mEq} / 1 \\
\text { Mean (SD) }\end{array}$ & $\begin{array}{l}5.2 \\
(0.45)\end{array}$ & $\begin{array}{l}5.4 \\
(0.38)\end{array}$ & $\begin{array}{l}5.7 \\
(0.33)\end{array}$ & $\begin{array}{l}5.5 \\
(0.54)\end{array}$ & $\begin{array}{l}5.2 \\
(0.39)\end{array}$ & $\begin{array}{l}5.4 \\
(0.47)\end{array}$ \\
\hline
\end{tabular}

* Hypopthesis testing (student's- $t$ test) for all variables showed $p>0.05$ 


\section{Treatment failure}

During observation until the infant reached the age of 96 hours, there were 8 patients who failed (needed mechanical ventilation) in the placebo group, and 7 patient in the dobutamine group, including 1 patient with increased systolic blood pressure up to $>85$ mmHg. An $x^{2}$ test for 2 independent groups showed no significant difference between dobutamine and placebo groups. See Table 3.

Table 3. Results of treatment in dobutamine and placebo groups

\begin{tabular}{llll}
\hline & Failure & Success & Total \\
\hline Placebo & $8(38 \%)$ & $13(62 \%)$ & 21 \\
Dobutamine & $7(35 \%)$ & $13(65 \%)$ & 20 \\
\hline
\end{tabular}

Relative risk: 1.10 (CI 95\%: 0.48; 2.44); $p=0.837$

\section{Survival analysis}

As mentioned earlier, since the time of the occurence of failure was as important as the incidence of failure, survival analyses were performed. First, survival analysis of all patients was performed, followed by comparison of survivals between placebo and dobutamine groups. The event of interest was when the patient needed mechanical ventilation, or when a life threatening condition occurred. Based on the natural history of HMD, that the active process of the disease usually subsides after the age of 72 to 96 hours, sur- vival analysis was done until the infant reached the age of 96 hours.

Analysis was done using the SPSS Program for Windows Release 6.0, with Kaplan-Meier method and Breslow hypothesis testing. The entry for time was the period (in hour) from the beginning of treatment and the event (failure). Entry for status was failed (score 1) or censored (unknown, meaning that until the age of 96 hours the patient still survived from failure). In this series none of the patients was loss to follow-up. To compare the survivals between the two groups, entry for factor was dobutamine (1) and placebo (0).

Table 4 is the survival table of the 41 patients; 15 patients failed and 26 patients were censored. The mean survival was 70 hours, with the $95 \%$ confidence intervals from 63 to 78 hours. Figure 2 shows the survival curve of all patients (41) according to Table 4. From both the table and figure it is seen that there were only 2 events occurred during the first 24 hours; the rest of the events were more or less equally distributed within the second and third 24 hour period.

Table 5 and Figure 3 shows survival comparison of patients of the placebo group $(n=21)$ and dobutamine group $(n=20)$. In the placebo group 8 patients failed with the mean survival rate of 61 (95\% confidence intervals 51 to 71) hours, while in the dobutamine group 7 patients failed (survival rate 78 hours with $95 \%$ confidence intervals from 70 to 84 hours). Breslow test shows a significant difference between the two groups.

Table 4. Life table (Kaplan-Meier) in 41 patients with mild HMD

\begin{tabular}{rcccl}
\hline Time (hours) & Cummulative survival & Standard Error & Cummulative failure & \\
\hline 3 & 0.98 & 0.02 & 1 & No. of cases $=41$ \\
15 & 0.95 & 0.03 & 2 & No. censored $=26(63.4 \%)$ \\
24 & 0.93 & 0.04 & 3 & No. of failure $=15(36.6 \%)$ \\
26 & 0.9 & 0.05 & 4 & Mean survival $=70($ CI $95 \%:$ \\
32 & 0.88 & 0.05 & 5 & 63 to 78$)$ hours \\
39 & 0.85 & 0.06 & 6 & 7 \\
44 & 0.83 & 0.06 & 8 & \\
60 & 0.8 & 0.06 & 9 & 10 \\
62 & 0.77 & 0.07 & 12 & \\
64 & 0.74 & 0.07 & 13 & \\
66 & 0.7 & 0.08 & 14 & \\
74 & 0.62 & 0.09 & 15 & \\
78 & 0.58 & 0.09 & 0.1 & \\
\hline
\end{tabular}




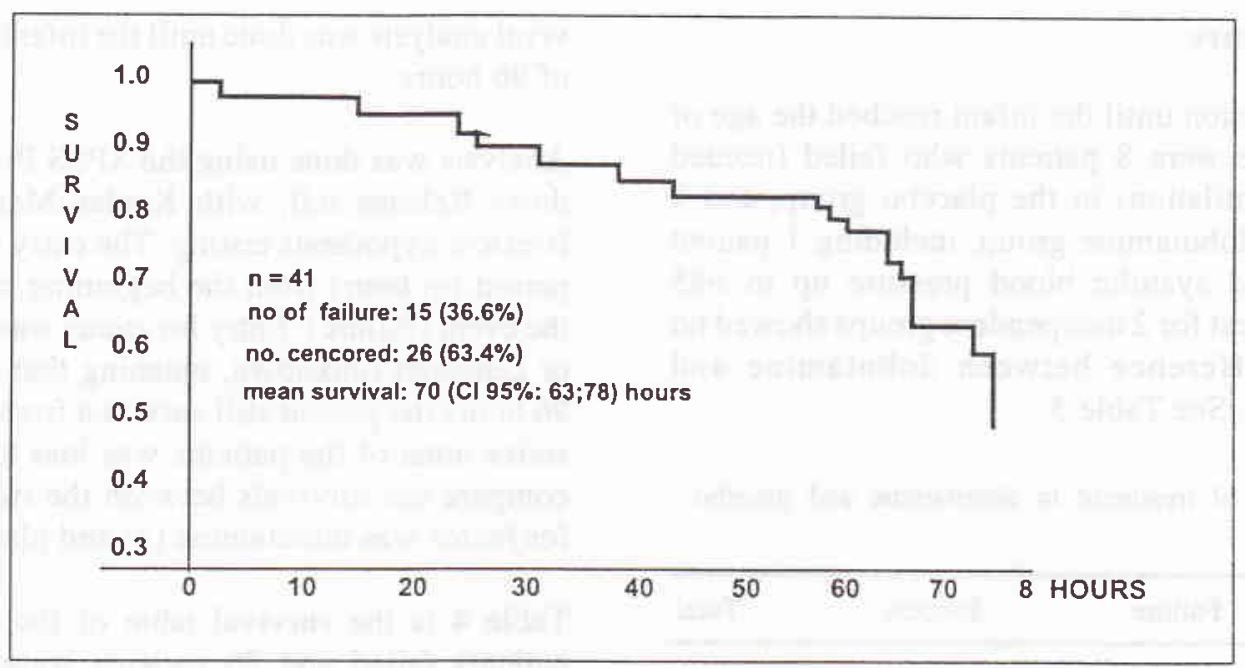

Figure 2. Kaplan-Meier curve shows mechanical ventilation or clinical deterioration free survival of 41 patients with mild HMD.

Table 5. Comparison of survivals of HMD patients in dobutamine and HMD groups

\begin{tabular}{|c|c|c|c|c|c|c|c|}
\hline \multicolumn{4}{|c|}{ Placebo } & \multicolumn{4}{|c|}{ Dobutamine } \\
\hline $\begin{array}{l}\text { Time } \\
\text { (hours) }\end{array}$ & $\begin{array}{c}\text { Cumulative } \\
\text { survival }\end{array}$ & $\begin{array}{c}\text { Standard } \\
\text { Error }\end{array}$ & $\begin{array}{c}\text { Cumulative } \\
\text { survival }\end{array}$ & $\begin{array}{l}\text { Time } \\
\text { (hours) }\end{array}$ & $\begin{array}{l}\text { Cumulative } \\
\text { survival }\end{array}$ & $\begin{array}{c}\text { Standard } \\
\text { Error }\end{array}$ & $\begin{array}{c}\text { Cumulative } \\
\text { survival }\end{array}$ \\
\hline 3 & 0.95 & 0.05 & 1 & 15 & 0.95 & 0.05 & 1 \\
\hline 26 & 0.9 & 0.06 & 2 & 60 & 0.90 & 0.07 & 2 \\
\hline 32 & 0.86 & 0.08 & 3 & 64 & 0.85 & 0.07 & 3 \\
\hline 37 & 0.81 & 0.09 & 4 & 67 & 0.75 & 0.10 & 5 \\
\hline 39 & 0.76 & 0.09 & 5 & 74 & 0.69 & 0.11 & 6 \\
\hline 44 & 0.71 & 0.10 & 6 & 78 & 0.62 & 0.12 & 7 \\
\hline 62 & 0.61 & 0.13 & 7 & & & & \\
\hline 66 & 0.49 & 0.15 & 8 & & & & \\
\hline
\end{tabular}

No. of cases $=21$

No. censored $=13(61.9 \%)$

No. of failure $=8$

Mean survival $=61(\mathrm{CI} 95 \%: 51 ; 71)$ hours

No. of cases $=20$

No. of censored $=13(65.0 \%)$

No. of failure $=7$

Mean survival $=78$ (IK 95\%: 70;84) jam

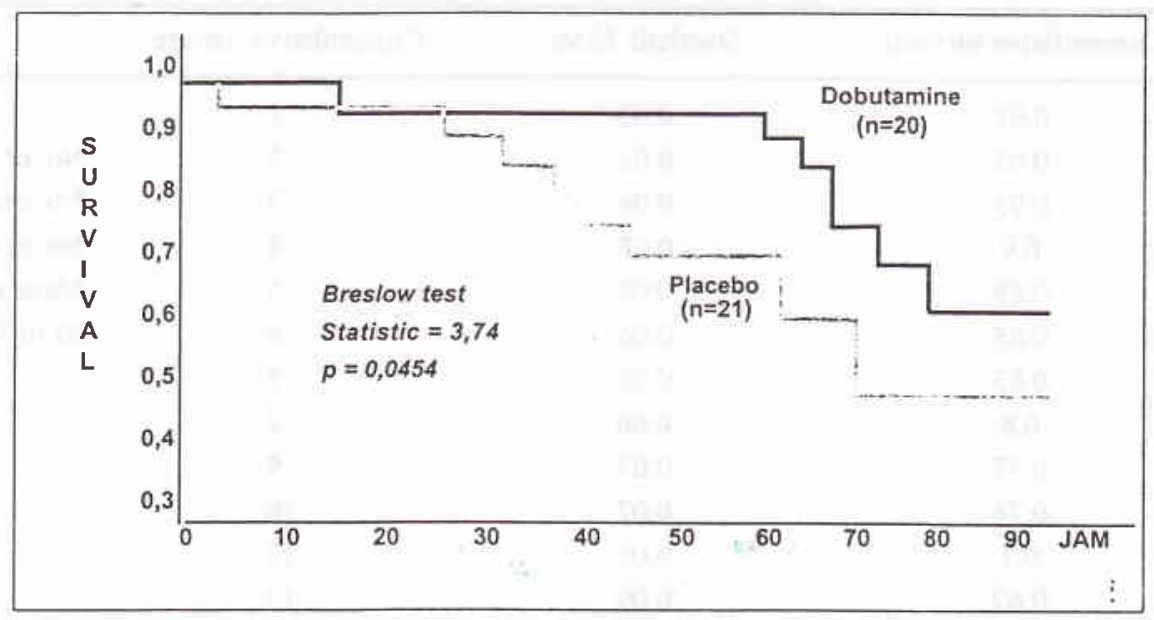

Figure 3. Kaplan-Meier curves show comparison of survivals (mechanical ventilation or clinical deterioration free) of patients with mild HMD treated with placebo or dobutamine. 


\section{Intracranial hemorrhage}

Examination for the possibility of intracranial hemorrhage was done with a head ultrasonography, on day-3 or 4 after birth. Data collected from 27 patients, show that 7 had intracranial hemorrhage, i.e., 4 out of 15 patients of the dobutamine group and 3 out of 12 patients of the placebo group.

\section{Side effects}

During the observation the only side effect was increase of systolic blood pressure (up to $85 \mathrm{mmHg}$ ) found in a patient of the dobutamine group approximately 15 hours after the start of dobutamine administration. This patient was then excluded from the study and considered failed.

\section{DISCUSSION}

Of the 41 patients studied, 20 patients received dobutamine and 21 received placebo; the differences of all clinical and laboratory parameters of both groups were not clinically important. The study was terminated as the infant reached the age of 96 hours. The main reason, as put forward earlier, because of the natural history of the disease. ${ }^{4}$ Furthermore, many of preterm infants with HMD who survive from their critical period, not infrequently suffer from many complications, e.g. hyperbilirubinemia, diarrhea, sepsis, meningitis, etc. which may lead to death. At the age of 96 hours, on the one hand the active process of HMD is over, and on the other hand the presence of any complication, especially nosocomial infection which is the main threat in preterm infant care, ${ }^{10}$ has not appeared yet.

Analysis of clinical parameters, i.e., vital signs after dobutamine or placebo administration, was done by comparing values at hours 24,48 , and 60 , as seen in Figure 1 . It shows that the heart and respiratory rates were not significantly different, while mean arterial pressure of the two groups was different. These findings showed that dobutamine administered for a relatively long time (3 days) did not cause significant changes on heart and respiratory rates, but it could maintain its effect on increasing the mean arterial pressure. It should be noted that since some of the infants died or were excluded from the study and some data could not be obtained, the number of infants was decreasing with time.

On laboratory results comparison (Table 4-15) it is obvious that in all parameters there were no significant differences between the two groups (hypothesis testing was done only on the data at hour 60). The question is, why did clinical (especially vital signs, excepts the blood pressure) and laboratory characteristics between the two groups not differ despite difference in survivals? This can be explained by the fact that almost all of the patients entered the study in a relatively stable condition. During hospitalization some of them developed clinical and/or laboratory deterioration that made them excluded from the study. Patients who were excluded from the study must have had clinical and laboratory deterioration, but they were not analyzed.

\section{Treatment failure}

The proportions of failure in both groups were similar, which were 7 out of 20 subjects in the dobutamine group and 8 out of 21 subjects in the placebo group (Table 5). Based on this finding it can be concluded that dobutamine does not reduce the number of patients with mild HMD who need mechanical ventilation in the first 4 days. This comparison was done with the number of subjects less than what was actually needed (recalculation showed that the power of the study was not $80 \%$; instead it has decreased to $67 \%$ ). It shows that the incidence difference between the two groups was clinically not important. However, there was one patient in the dobutamine group who was excluded from the study due to increased blood pressure. Had this patient not been considered failed, then the conclusion should have been that dobutamine decreases the need for mechanical ventilation more than $20 \%$, a figure that should be considered if it is applied on hundreds of thousand HMD patients in the community.

To find out whether there was any clinical and laboratory difference (at start of therapy) between patients who failed and survived, a comparison was done (data not shown). It was found that there were no significant clinical nor laboratory differences between the two groups. In other words, the clinical and / or laboratory condition at the beginning of the course of the illness is not a good predictor for the later need of mechanical ventilation. This is in accord with the natural history of HMD, that many patients who are at first diagnosed as having a mild illness tend to worsen in 48 hours, then relatively stable, and gradually improve after 72 hours. At the time of deterioration, some patients might have respiratory failure so that they needed mechanical ventilation. These patients could not be predicted based on clinical or laboratory findings early in the clinical course of the disease. 


\section{Survival analysis}

In daily medical practice, both from the doctor and the patient points of view, the time of the occurrence of an event is just as important as the occurence of the event itself. This fact is often overlooked in analyzing a study result, which may affect its application in the management of patients. To avoid this, an analysis considering the time of occurrence (time-dependent analysis) or time to event data, ${ }^{11}$ should be performed. Usually, this analysis is mainly done to evaluate the results of treatment of malignancy, i.e. cancer or leukemia. Ideally this analysis should be done in various diseases, since even if both groups have similar incidence rate, but if the time of the occurrence of the event differs, this may give a benefit in managing the subsequent patients. For that reason, survival analysis had been designed since the beginning of this study. There are several ways to construct survival analysis, the two most popular ways are the actuarial method (Cutler-Ederer) and the Kaplan-Meier method. ${ }^{12}$ Both methods usually give similar curves, eventhough sometimes they don't. There are also numerous techniques for testing the hypothesis in survival analysis. In this study Kaplan-Meier method was used for summarizing survival data, with Breslow method for hypothesis testing. The results show that the two groups differed significantly in how long a patient was free from mechanical ventilation or fatal complication. With the limited number of subjects, the data supported the hypothesis that inotropic agent administration delays the need for mechanical ventilation, or put in other way, dobutamine delays the progress of the disease.

A delay of the need for mechanical ventilation can be explained with 2 definite reasons and 2 probable reasons. The 2 definite reasons are: (1) improvement of diastolic and systolic functions due to dobutamine administration and increase of mean arterial pressure will decrease the degree of circulus vitiosus. Improvement of ventricular functions and increase of mean arterial pressure in dobutamine group result a more stable cardiovascular system compared to the placebo group; and (2) dobutamine has positive effects on the secretion and distribution of surfactant. Other possible positive effects of dobutamine are: (1) dobutamine decreases pulmonary vascular pressure; (2) dobutamine may increase surfactant production. ${ }^{4}$

\section{Side effects}

On clinical and laboratory observations no dobutamine side effect was found, except one patient who showed an increased systolic blood pressure on day 1 of dobutamine administration. This patient was delivered through a cesarean section with gestational age of 32 weeks, with the first minute Apgar score of 4 . Ten hours after dobutamine infusion the blood pressure increased from $62 / 36 \mathrm{mmHg}$ to $76 / 42 \mathrm{mmHg}$, and 15 hours after dobutamine administration it became $85 / 58$ $\mathrm{mmHg}$. Although clinical or laboratory deterioration was not observed, it was finally decided to terminate the trial, and the patient was treated as usual.

\section{Role of patent ductus arteriosus}

Studies on preterm infants always involve the presence of patent ductus arteriosus (PDA). The prevalence of PDA is inversely related to gestational age; the less the gestational age the larger the proportion of infants with PDA. In full-term infants, the incidence of PDA is about 1 per thousand livebirths, ${ }^{13}$ while in infants with 32 weeks gestational age the significant incidence is about $25 \%$, and in 28 weeks or less the incidence became more than $50 \%$.

In infants and children, moderate and large degrees of PDA causes a left to right shunt that may cause heart failure which would affect the respiratory system. ${ }^{14}$ In full-term and preterm infants without HMD, in the first 2-3 days after birth, usually PDA has not manifested itself. The infants do not suffer from distress, and even on physical examination a heart murmur may not be found, or only systolic murmur is heard. This is because in the first days of life the pulmonary vascular resistance is still high, so there is no significant pressure difference between the aorta and pulmonary artery, and no significant shunt occurr. ${ }^{15}$ If the pulmonary vascular resistance decreases then a significant left to right shunt will occur.

The same thing happen in preterm infants with HMD or PDA; in the first 2 or 3 days of the HMD course, the pulmonary vascular resistance is still high so that no significant left to right shunt is present. As the HMD improves, the pulmonary vascular resistance decreases and causes a significant pressure difference between the aorta and pulmonary artery. In result a significant left to right shunt is present. In preterm infants with HMD and large PDA large left to right shunt may follow causing reappearance of dyspnea as a manifestation of heart failure.

In this series, of 41 HMD cases there were 21 patients with PDA, diagnosed with echocardiography and Doppler. During the first examination there were only 2 cases with low grade systolic murmur and none of them 
had continuous murmur. On high parasternal short axis view a duct could be detected on the left side of the pulmonary artery branch. By using the color Doppler a continuous flow could be seen in the duct and the main pulmonary artery, ${ }^{16-18}$ usually with a low diastolic component. An M-mode examination showed a normal left atrium dimension meaning that the duct was hemodynamically not significant.

Some authors study the blood flow patterns of the arterial duct in preterm infants, ${ }^{17,19-20}$ including the effect of PDA to the ventricular functions and organ blood flow. In preterm infants, a large PDA may give a significant effect in infants without HMD or in infants who have recovered from $\mathrm{HMD}$. In such cases, not only the infant is prone to heart failure but a change of the cerebral blood flow may also happen. ${ }^{21}$ These infants are good candidates for indomethacin or other anti-prostaglandin drugs to close the duct ${ }^{13,22-25}$ which are believed to decrease the incidence of periventricular-intraventricular hemorrhage. ${ }^{26,27}$ Since all the subjects in this series did not show any significant PDA, the presence of PDA was not included in the analysis.

To sum up, this study shows that dobutamine could alter the clinical course of patients who were initally diagnosed as having mild HMD. Definite practical implication of this result needs further confirmation, as medical knowledge is not built only from experience of some patients but as a result of accumulation of experience with hundreds or thousands of patients. For the time being, however, the author think that suffice it to suggest to administer dobutamine 10 $\mu \mathrm{g} / \mathrm{kg} /$ minute to all preterm infants with HMD who do not need mechanical ventilation besides standard supportive treatment. For rural hospitals or those which are not equipped with neonatal intensive care facilities, a delay of the need for mechanical ventilation gives a chance to the doctor in charge to modify treatment or to refer the patient to a better equipped hospital.

\section{ACKNOWLEDGMENTS}

The author wishes to thank Professor Hans E Monintja, MD, Professor Sofyan Ismael, MD, and Professor Bambang Madiyono, MD for continuously supervising the study and reviewing the article, to Asril Aminullah, $\mathrm{MD}$ and the Perinatology Staff for supervising patient management, to Kemas Firman, MD, for performing ultrasonographic examination, and to Dyani Kusumowardhani, MD for helping with manuscript preparation. This study was partly funded by 'Tim
Manajemen Program Doktor' (Department of Education and Culture, Republic of Indonesia), South-East Regional Office (SEARO) - WHO, Manila, The Management of 'Riset Bimbingan Ilmu Pengetahuan dan Teknologi Kedokteran' (National Research Council), PT Solvay Pharmaceutical Indonesia, PT DexaMedica, and PT Kimia Farma. Dobutamine and placebo were prepared and supplied by Solvay Pharmaceutical, Hannover, Germany.

\section{REFERENCES}

1. Hjalmarson O. Epidemiology and classification of acute neonatal respiratory disorders. Acta Paediatr Scand 1981; 70:773-8

2. Martin RJ, Fanaroff AA. The respiratory distress syndrome and its management. In: Fanaroff AA, Martin RJ, eds. Neonatal-perinatal medicine. Diseases of the fetus and infant. 6th ed. St Louis: Mosby; 1997. p. 1018-27.

3. Jobe AH. Lung development. In: Fanaroff AA, Martin RJ, eds. Neonatal-perinatal medicine. Diseases of the fetus and infant. 6th ed. St Louis: Mosby; 1997. p. 991-1008.

4. Walsh MC, Carlo W, Miller MJ. Respiratory diseases of the newborn. In: Carlo WA, Chatburn RL, eds. Neonatal respiratory care. 2nd ed. Chicago: Year Book; 1988. p. 260-88.

5. Gregory GA. Treatment of the idiopathic respiratory distress syndrome with continuous positive airway pressure. N Engl J Med 1971; 24:1333-40.

6. Fujiwara $T$, Konishi $M$, Chida $S$. Surfactant therapy in neonatal respiratory distress syndrome. In: Yeh TF, eds. Neonatal therapeutics. 2nd ed. St Louis: Mosby; 1991. p. 70-86

7. Tambunan T, Monintja HE, Karyomanggolo WT, Tamaela LA. Gambaran radiologis paru pada bayi baru lahir dengan 'respiratory distress'. Maj Kedokt Indones 1978; 28:109-16.

8. Monintja HE. Perinatologi dan hubungannya dengan kualitas manusia. Pidato Pengukuhan Guru Besar FKUI. Jakarta: Balai Penerbit FKUI, 1989.

9. Brady JP, Gregory GA. Assisted ventilation. In: Klauss MH, Fanaroff AA, eds. Care of high-risk neonate. 3rd ed. Philadelphia: Saunders; 1986. p. 202-18.

10. Monintja HE. Infeksi sistemik pada neonatus. In: Yu VYH, Monitja HE. Beberapa masalah perawatan intensif neonatus. Jakarta: FKUI; 1997. p. 217-30.

11. Altman DG, Bland JM. Time to event (survival) data. Brit Med J 1998; 317:468-9.

12. Sastroasmoro S, Firmansyah A, Said M, Akib AP. Analisis kesintasan. In: Sastroasmoro S, Ismael S, eds. Dasar-dasar metodologi penelitian klinis. Jakarta: Binarupa Aksara; 1995. p. 143-55.

13. Yu VHY, Monintja HE. Duktus arteriosus persisten pada neonatus. In: Yu VYH, Monitja HE. Beberapa masalah perawatan intensif neonatus. Jakarta: FKUI; 1997. p. 57-76.

14. DiCarlo JV, Steven JM. Respiratory failure in congenital heart disease. Pediatr Clin North Am 1994; 41:525-42.

15. Drayton MR, Skidmore R. Ductus arteriosus blood flow during first 48 hours. Arch Dis Child 1987; 62:1030-4. 
16. Shimade S. Effect of PDA on left ventricular output and organ blood flow in preterm infants with respiratory distress syndrome treated with surfactant. J Pediatr 1994; 125:270-7.

17. Hirsimaki H, Kero P, Wanne O. Doppler ultrasound and clinical evaluation in detection and grading of patent ductus arteriosus in neonates. Crit Care Med 1990; 18:490-3.

18. Su B-H, Watanabe T, Shimizu M, Yanagisawa M. Echocardiographic assessment of patent ductus arteriosus shunt flow pattem in premature infants. Arch Dis Child Fetal Neonatal 1997; 77:F36-40.

19. Macdonald FD, Yu VYH. Simultaneous measurement of preductal and postductal oxygen saturation by pulse oximetry in hyaline membrane disease. Arch Dis Child 1992; 67:1166-8.

20. Clyman RI. Ductus arteriosus. In: Gluckman PD, Heymann MA, eds. Pediatrics and perinatology - the scientific basis. Edisi ke-2. London: Amold; 1996. p. 755-61.

21. Mahony L, Caldwell RL, Girod DA, Hurwitz RA, Jansen $\mathrm{RD}$, Lennons JA, et al. Indomethacin therapy on the first day of life in infants with very low birthweight. J Pediatr 1985; 106:801-5.
22. Kueger E, Mellander M, Bratton D, Cotton R. Prevention of symptomatic patent ductus arteriosus with a single dose of indomethacin. J Pediatr 1987; 111:749-54.

23. Rennie JM, Doyle J, Cooke RWY. Early administration of indomethacin to preterm infants. Arch Dis Child 1986; 61:233-8.

24. Yeh TF, Luken JA, Thalji A, Raval D, Carr I, Pildes RS. Intravenous indomethacin therapy in premature infants with persistent ductus arteriosus: a double-blind controlled study. J Pediatr 1981; 98:137-45.

25. Ment LR, Duncan CC, Ehrenkranz RA, Kleinman CS, Pitt $\mathrm{BR}$, Taylor $\mathrm{KJW}$, et al. Randomized indomethacin trial for prevention of intraventricular hemorrhage in very low birthweight infants. J Pediatr 1985; 107:937-43.

26. Bada HS, Green RS, Pourcyrous M, Leffler CW, Korones $\mathrm{SB}$, Magill HL, et al. Indomethacin reduces the risks of severe intraventricular hemorrhage. J Pediatr 1989; 115:6317.

27. Hanigan WC, Kennedy G, Roemisch F, Anderson R, Kusack $\mathrm{T}$, Powers W. Administration of indomethacin for the prevention of periventricular-intraventricular hemorrhage in high risk neonates. J Pediatr 1988; 112:941-7. 